\title{
Cyclic Vitalism: The Dialectics of Life and Death in German Poetry around $1900^{*}$
}

\author{
Sven Halse \\ Dept. of Aesthetics and Communication, Aarhus University, Aarhus, Denmark \\ Email: $\underline{\text { slksh@dac.au.dk }}$
}

Received November $17^{\text {th }}, 2013$; revised December 20 $0^{\text {th }}$, 2013; accepted January $4^{\text {th }}, 2014$

\begin{abstract}
Copyright (c) 2014 Sven Halse. This is an open access article distributed under the Creative Commons Attribution License, which permits unrestricted use, distribution, and reproduction in any medium, provided the original work is properly cited. In accordance of the Creative Commons Attribution License all Copyrights (c) 2014 are reserved for SCIRP and the owner of the intellectual property Sven Halse. All Copyright (C) 2014 are guarded by law and by SCIRP as a guardian.
\end{abstract}

Over the past decade, Scandinavian and German scholars have been active in the redefinition of the terms "Vitalism" and "Vitalist" as descriptive categories for analytical purposes in the fields of literary and cultural history. In this context, "Vitalism" has primarily been used to describe an enthusiastic worshipping of life, one that holds youth, health, strength and beauty as its primary attributes, which was prevalent in all aspects of cultural life around 1900. But even the post war founders of the Vitalist re-conceptualisation of this era, Wolfdietrich Rasch and Gunter Martens, warned of taking such a unilateral view of what constituted a Vitalist concept of life. It could lead to a misunderstanding of Vitalist way of thinking, Rasch said, if the focus was only set upon the enthusiastic surplus, the worshipping of youth and health. To Vitalists, life is more than that. It is a totality that also encompasses notions of destruction, decay and death. "All life symbols in literature around 1900 are at the same time symbols of death" (Rasch, 1967: 24). Through the analyses of three poems, this article aims to show concrete examples of how cyclic Vitalist thinking is embedded in poetry of the era. The analyses include a further sub-categorisation to capture the different types of Life Force dealt with in the texts. By way of an introduction, Vitalism is discussed within the context of the scientific and social developments of the $19^{\text {th }}$ Century.

Keywords: Vitalism; German Literature; German Poetry; Life Reform Movement; Life Force

\section{Life as a New Formula for Mankind around 1900}

Between 1890-1930 the word life took on almost religious connotations. The literary index and our examples are primarily taken from the German speaking area, and they are abound with life-related titles: Triumph des Lebens [Triumph of Life] ${ }^{1}$, Eslebe das Leben [Long Live Life] ${ }^{2}$, Lobgesang des Lebens [Hymn on Life] $]^{3}$, Der Ruf des Lebens [Call of Life] ${ }^{4}$, Hymnen an das Leben [Hymns to Life] ${ }^{5}$, DerSieg des Lebens [Victory of Life $]^{6}$. This phenomenon is not, however, limited to the German speaking region, and can be observed in the whole of Europe and USA as well.

Not only arts and philosophy, but also to a very large extent natural science, in this period dealt with the enigma of life; in

\footnotetext{
*This paper is a revised and abridged version of a formerly published contribution in German, see bibliography: Halse, S. (2013).

${ }^{1}$ Hart, Julius: Triumph des Lebens. Florenz und Leipzig: Eugen Diederichs, 1898.

${ }^{2}$ Sudermann, Hermann: Es lebe das Leben. Drama in fünf Akten. Stuttgart/Berlin: Cotta, 1902.

${ }^{3}$ Schmidtbonn,Wilhelm:, Lobgesang des Lebens. Rhapsodien. Berlin: Egon Fleischel, 1911.

${ }^{4}$ Schnitzler, Arthur: Der Ruf des Lebens. Drama in 5 Akten. Berlin: Fischer Verlag, 1906.

${ }^{5}$ Verhaeren, Emile: Hymnen an das Leben (Übersetzung von Stefan Zweig). Leipzig: Insel-Verlag, 1912.

${ }^{6}$ Bölsche, Wilhelm: Der Sieg des Lebens. Stuttgart: Kosmos, 1905.
}

fact, the term Vitalism is used primarily within the paradigm of natural science-or natural philosophy, as opponents of Vitalism would tend to say. In a search for the innermost mechanisms of life, a group of scientists proposed the theory of a Life Force. The Vitalists or "Neo-Vitalists", who had been philosophers with similar beliefs before-were convinced that life could be ascribed to this specific force of nature, a force that encompassed information of life forms and ensured the optimal reproduction and formation of the individuals. The best-known representative of this school was Hans Driesch (1867-1941), Professor at the University of Cologne. He named this universal life force "Entelechy", borrowing this appellation from Aristotle, whom he regarded the true originator of Vitalism (Driesch, 1922). The concept of life as a self-directed, indivisible natural force like gravity and electricity emerged in Hans Driesch's laboratories in the years 1896-1900. These were also the years, when Henri Bequerel and Marie Curie established the existence of radioactivity, a discovery, which confirmed Driesch's belief that there were still natural forces that had not yet been proven by experiment.

Opposite to the theory of a Life Force, "Mechanists" claimed that life was to be understood as an isolated chemical function within the physical substance ${ }^{7}$. This was-as we now knowto be the prevailing position in modern science, even though

\footnotetext{
${ }^{7}$ See for instance Hein, H. (1972).
} 
many new realisations have been added since then, not the least the existence and function of DNA and the genome.

But the conception of an autonomous Life Force was in good harmony with the thinking of the era, whether this thinking derived from the paradigm of natural science or from the philosophical sphere. Friedrich Nietzsche, for instance, had reflected upon life in new and provocative ways since the 1870s. Through his deliberations he came to place the concept of life in opposition to the idea of civilisation: "life" for Nietzsche meant candid, natural, biological, animalistic, instinctive. Praising "life itself" meant recognizing man's biological destiny "beyond good and evil", his dependence on evolution and rules of nature-and taking pride in it. A prominent symbol of this "natural turn" was the naked body: the human creature stripped of its civilizational symbols and loads; a sublime animal set free to seek a new beginning for mankind.

Neo-Vitalism may be understood as an attempt by western culture to overcome the perceived loss of human dignity associated with the biological turn of $19^{\text {th }}$ Century science, Darwinism being its paradigmatic representative. The specific Vitalistresponse was a canonisation of life as an autonomous force of a pseudo-divine status.

Natural science of the late 19th Century had demonstrated man to be an animal among other animals. Though he distinguished himself through his intelligence and culture, he was exposed to the very same evolutionary and biological laws, as were all other creatures on earth. It therefore was not easy to uphold the image of man as created in the likeness of God. Furthermore, Darwin's maxim on the survival of the fittest was by some re-phrased into a doctrine of "the right of the strongest", and Darwinism thus to some became a threat to Christian ethics of charity and to humanistic ethics in general. Although Darwin had talked about "the fittest" and not "the strongest", the latter interpretation often dominated the messages of popular science. This can be seen in the instance of German "völkische” ideology (an expansive nationalist ideology based on a conception of the supremacy of the "Aryan race"), whose proponents tried to substantiate racial theories with "scientific" evidence.

The general understanding of nature as a battle, in which some species had to succumb, to some degree found its parallel and verification in the social development of the western countries. The poor social conditions of the lowest classes in the wake of industrialisation and the concentration of physical and moral decay in big cities, to some people seemed to expose the "fact" that the human race might not be fit for survival in this modern civilisation. Against the backdrop of this threat tohumankind, new visions for humanity's future arose, visions that lent towards a more natural and vital base. This eulogising of life alongside predictions of humankind's death and decay, the cult of décadence, is notable in that these two reactions, décadence and Vitalism, are often represented together in art.

The Life Reform Movement, in its many guises, indicates the contemporary culture's desire for a new vision of human dignity. Health, beauty and strength became keywords in this new vision, but their close neighbours, not to say their twins, were decay, degeneration and death.

\section{Vitalism as a Cyclic Concept}

The term "life" became as significant and essential to this era, as were the terms "sense" or "ratio" to the era of Enlightenment; according to German literary critic and authority in this field,
Wolfdietrich Rasch (Rasch, 1967: 17). In the 1960s, Rasch suggested that this life-enthusiastic trend in literature and culture should be emphasised in literary historiography, and be given its own appellation. Vitalism was already used in natural science and thus considered too "narrow", instead he suggested the term "Lebenspathos" (Life Pathos), however the term never gained support in the tradition of German literary historiography (Rasch, 1967: 20).

Four years after Rasch had pointed out the need for a way to express the cultural interest in "life" (and death) at the turn of the twentieth century, Gunter Martens in his dissertation Vitalismus und Expressionismus (Martens, 1971) insisted on the usability of the term Vitalism for describing this phenomenon. In so doing he prepared the ground forthe rediscovery of Vitalism by scholars and for the re-definition of the use of the term within cultural analysis. A further wave of interest in this work has arisen over the past ten years or so ${ }^{8}$.

In recent years scholars within the field of cultural history have made an effort to identify, describe and synthesise the increased significance of life as a problem and a subject of adoration in the arts, philosophy and everyday culture in the period 1890 until approximately 1930, or in some cases even later. Such studies have tended to use a re-definition of the concept of Vitalism that goes beyond the term as conceived by natural scientists.

"Vitalism" and "Vitalist" in a cultural analytic context are thus to be understood as defining a category that describes phenomenon in art, literature and other artistic expressions, but also in other cultural forms like organisational programs, political programs etc. In earlier articles (Halse, 2007, 2009), a typology pointing out four domains of Vitalist expression has been suggested: artistic, philosophical, scientific and pragmatic Vitalism. Sports historian Hans Bonde has suggested the following definition of Vitalism in a broader sense: "Vitalism is a cultural current, that manifests itself in philosophy, arts and everyday life through an emphasis on the active sides of life, the forward striving youth, the dynamic personality and the potentials of the body, and with a sting against rationalism, intellectualism and unilateral worshipping of the mind" (Bonde, 2005: 9, translated by SH).

Hans Bonde's definition resonates with many recent discussions of Vitalist features in cultural life in the early $20^{\text {th }}$ Century. Such discussions have to a large degree focussed on the "positive" aspect of the life-theme, i.e. on health, strength and beauty; what one might call the affirmation of life. Youth and love of life have often been accentuated as characteristics of the Vitalist way of thinking. And for a sports historian this is very natural. But also within other parts of cultural history, Vitalism has been seen in opposition to the decadent fin de siècle-cult, in which diseases and bad spirits are understood as prerequisites for sublime art.

By unilaterally stressing the life-affirmative aspect of Vitalism, however, there is a risk of trivialising and vulgarising what Vitalism is actually about, and thus providing a platform for those who want to portray Vitalism as nothing but kitsch and

${ }^{8}$ Many articles and some books have contributed to the re-discovering of the vitalist current in primarily Scandinavian and German Arts. They cannot all be mentioned here; a recent selection of titles in English and German (in alphabetical order) could include: Andersen, L.P. (2011); Bühler, B. (2004); Dam, A.E. (2011); Halse, S. (2011); Hvidberg-Hansen, G. (2011), Munch, A.V. (2011); Nørlyng, O. (2011); Oelsner, G. (2011); Riedel, W. (1996). The number and importance of the contributions in Danish and other Scandinavian languages by far outweigh those in German and English. 
early fascism.

\section{Excurse: Vitalism and Fascism}

One or two words should be said about the relation between Vitalism and fascism. They have many motifs in common: the preference for youth, health, beauty, strong bodies, sports and physical activities, and so forth. This can partly be ascribed to the fact that all popular movements, be it the scout movement, the hiking-societies (Wandervogel-Bewegung), associations for sports of any kind, for healthier living (vegetarianism, nudism etc.) were ideologically aligned with the Nazi-programme in the 1930s, or else forbidden (Gleichschaltung, "Unification”); their message of a healthier mankind was steered into the Nazi racial ideology with the optimization of the "Aryan” race as its main goal. Not all members and sections of the early Life Reform Movement were unfamiliar to this kind of racial thinking. "Völkische" ideology had found some foothold in the German Kaiserreich from the late $19^{\text {th }}$ Century onwards. The Nazis in the 1920s did not invent “Aryan” racial thinking, but like most other things that came into their horizon of interest, they intensified, systematised and de-humanised, and in some cases distorted it. Anti-Semites and racists we find in the early Lebensreform as well as in other parts of German society around 1900. Some of these reformers like the early Garden City creator Theodor Fritsch or the well-known artist Fidus (Hugo Hoeppener) later put themselves at the disposal of the Nazi regime, without reservation. Others tried as long as possible to stay on an alternative path, and then disappeared in one way, or the other.

There is no reason to try to white-wash theVitalist movement, as there is no such thing as a "clean" sphere free of racist, antisemitic, "völkisch" ideology in the first half of the $20^{\text {th }}$ Century. Whether the density of those with racist beliefs was higher in the Life Reform Sphere than average, has not- to my knowledge-been studied. In general we can state that a great fascination for the life-question and interest in what was understood as the Life Force can be noticed right across the cultural and political scene, from Frank Wedekind to Hermann Hesse, from the young Bertolt Brecht to Ernst Jünger.

\section{The Concept of "Cyclic Vitalism"}

We will now turn back to the concept of Vitalism as a tool of analysis. An elaboration of the until now relatively one-dimensional term Vitalism (cf. Hans Bonde's definition) will be necessary in order to reach a more nuanced understanding of the life-complex, or more precisely, the connection between life and death. As already noted, a unilateral focus on the life-affirmative side of Vitalism means an important dialectic dimension is ignored, i.e. the dialectics of life and death. Vitalism understands this relation as a cyclic one: Life, or the "Life Force", does not cease to exist with death, but merely changes its form and its "residence". Unlike Christian beliefs, Vitalist life does not return to any kind of Heaven, but stays connected to physical matter, without which it cannot exist: Life Force is seen as a completely earthly phenomenon, there is no dualistic transcendence into a sphere beyond the material or substantial one, according to Vitalist thinking. Because the Life Force is thought of as indivisible, it is the same force that is active every where and every time a new organism comes into life. Death and the processes connected to it therefore also are seen as parts of the total cyclic course of the Life Force.

Using this concept of Cyclic Vitalism, in the following analyses we will try to show how a few poets of this era Conceive the cyclic connection of life and death.

As mentioned above, the cyclic aspect of Vitalism has been pointed out by earlier scholars in this field, first and foremost Wolfdietrich Rasch (Rasch, 1967: 20f.) and Gunter Martens (Martens, 1971). Recently, Anders Ehlers Dam in his dissertation on Vitalism in Danish poetry (Dam, 2010) used the terms "positive" and "negative" Vitalism, by which he means a Vitalism that finds its solution of the life question in a "life ecstasy" or in a longing for death, respectively in death itself. Such valorising of concepts, however, seems less appropriate in the context of Vitalism, because life and death here are dialec- ticly connected, as already mentioned. Thus, "positive” and "negative" are valuating terms that do not do full justice to the cyclic nature of Vitalism.

The term Cyclic Vitalism, which is introduced in this article, wishes to capture exactly this matter: that Vitalist literature depicts life - in a broader sense of the word — on the one hand as growth, strength, youth and health, and on the other as its cyclic opposition, stasis, rigidity, decline, even death and disintegration.

Seen from an individual lyrical point of view, this totality of life seldom is encapsulated. Rather the totality of life will be dissolved into parts of individual life and individual death, individual excitement and individual decadence. The Vitalist text may accentuate one or another aspect of the total life cycle, without letting the dialectically corresponding aspects fall out of sight. Moments and segments of life symbolically represent highlights of a course, a cycle. The individual life or segment of life refers to the totality and achieves universality through this reference.

In some cases, however, the text surpasses the individual perspective and thematises the universal totality itself, either as a principle or as an individual experience of transcendence of the individual self (what you might call a kind of "Nirvana"-experience). Such poems are often motivated by the wish to convey a "momentary experience of the great coherence" ("Momenteeines Innewerdens des großen Zusammenhangs") (Rasch, 1967: 22). In such cases, one might say that the text accentuates the whole circle of life, from which other texts thematise only limited sections.

The following examples are chosen with an eye to this difference: the segment and the totality. Another differentiation that will be clarified along the way, has to do with the status of the Life Force in the universe: In some cases the Life Force is presented in extremely palpable, physical contexts, in others we find it hovering above the world. It is the same Life Force, only the conceptualisation and realisation of it can take very different forms. And form, or literary expression, of course, is of primary interest for the purposes of this discussion.

\section{Three Poems of Life and Death}

Julie Virginie Scheuermann (with the nom de plume Julia Virginia, (1878-1936) is quite unknown to the literary world of today. In most histories of literature one will look in vain for her name. In her contemporary time, however, she was promising enough to be selected for the Reclam-volume Moderne deutsche Lyrik [1903]. This book, which was edited by Hans Benzmann, a poet himself, contained around 650 poems and 
can be considered representative of the era under study (Benzmann, 1903).

In her youth, Julia Scheuermann published two volumes of her own poetry and edited a volume Frauenlyrikunserer Zeit (1907); furthermore, she edited a collection of poems by Annette von Droste-Hülshoff (1910). Droste’s well-known emancipatory poem "Am Turme" ("On the Tower") seems to have inspired the poem "Leben!" which isto be analysed here "Leben!”, was published in 1903 as part of her Primitien collection. For the purpose of this analysis only the first and last of four stanzas need to be quoted (and translated) to give the reader a sufficient impression of the style and content of the text:

Leben, du purpurner, quellender Sprudel, ich möchte mit beiden Händen dich fassen, möchte mich stürmisch umtosen lassen

von deiner Brandung bacchantischem Strudel!

Möchte mich stürzen in deinen Schlund

Jauchzend, mit gierig geöffnetem Mund!-

Möcht sie entlodern lassen die Gluten,

die scheu mich durchziehen, die der Erden entstammen,

in deines Taumels Champagnerfluten

zu blühenden, glühenden Flammen!

\section{[...]}

Und so stürz ich denn tollkühn, mit lachenden Lippen,

mit all meiner Jugend entfesselten Gluten,

Leben! In deinen purpurnen Fluten

durchstarrt von tausend zackigen Klippen,

in deines Malstroms Wirbelgetos,

in seiner Fluten hölltiefen Schoß;

ob er zum Lichte mich möge erheben,

ob ich im Strudel werde versinken-

Ihr Götter! nur leben, nur leben,

Nurtrinken!

[Life, you purple, gushing spring,

I wish to grasp you with both hands,

Wish to be enclosed by the stormy roar

From the bacchantic whirl of your breakers!

Wish to throw myself in your deep abyss

Rejoicing, with my mouth desirously opened!-

Wish to let the glows flare up,

That timidly run through me, they come from the Earth, In the champagne-floods of your turmoil

Into flowering, red hot flames!

\section{[...]}

And so I foolhardy with laughing lips,

Plunge with all the relieved flames of my youth,

Life! Into your purple floods,

Thousand jagged cliffs everywhere towering up

In the whirling noise of your maelstrom,

Into the hell-deep womb of its floods;

Whether it proudly may lift me to the light,

Or I may sink to the bottom of the whirl-

Ye Gods! Just live, just live,

Just drink!]

Here, the lyrical I hasbut one wish: to throw herself into this whirl of life without any long-term considerations of the consequences. This surrender to life means for one thing that the I turns into an object: she lets life do to her, what it wants
("möchtemichumtosenlassen”/“Wish to be enclosed by the stormy roar"); secondly it means that the I herself-like the maelstrom-is turned into an all engulfing subject, ("mitgieriggeöffnetemMund"/“with my mouth desirously opened”). She wants an immediate physical unification with life, i.e. to consume it into her body as a liquid: "nurtrinken!”/“Just drink!”, she continues immediately after the twice uttered "nurleben"/ "just live"; living in this case thus means "drinking life", taking life into her body.

The fusion and dissolving of the relation between subject and object is orchestrated as an erotic encounter: the "I" wants to "grasp life with both hands", to let it "roar all over her" ("umtosen"), she with her mouth desirously opened (not just "open”). The glowing in her, at the beginning just "timid" - through the encounter with life will grow to flames, so she expects. Other erotic references are "the glow of youth", "lips" and the womb of the stream ("in seiner FlutenhölltiefenSchoß”/“Into the hell-deep womb of its floods").

Special attention should be drawn to the quality of the inner fire of the subject. This fire of life stems from the Earth ("enstammen der Erden”) and thus surpasses the level of individual longing. It is a force that connects the individual to its universal origin. It would not be too daring to claim that the poem by assigning a cosmic quality to the individual's inner fire of life thereby refers to the conception of a Vitalist Life Force. As an individual taking part in this cosmic force, the Iinscribes herself into the universal community of life as such. Establishing and emphasising the community of all life is one of the main topics of Vitalism as Wolfdietrich Rasch points out:

"Diese Zugehörigkeit jeglicher Einzelerscheinung, auch des Ich, zum Gesamtleben ist der Kern jener Vorstellung, die das emphatisch gesprochene Wort Leben bezeichnet [...]. Leben ist für die Anschauungsweise der Zeit immer mehr als Einzelleben”. [This belonging of all singularities, also the "I" of the totality of life, is the kernel of that conception, that defines the emphatically spoken word "life" [...]. Life from this perspective is always more than the individual life" (Rasch, 1967: 21).

But the Iof this poem is not yet fully part of this totality; and that's where the drama of the poem lies. She has not yet been able to experience the unification with life. But an inborn glow and longing lies within her and tells her that she very soon must take a leap in order to reach this experience. This longing, and the tension between the "now" and an anticipated very near future, structures the dramatic curve of this poem.

By thematising the life-death-spectrum, this poem emphasises most strongly the life-affirming aspect, although death is mentioned as a possible consequence of complete surrender to life: "Whether it may lift me to the light, Or I may sink to the bottom of the whirl". Both destinies to her are equally acceptable results of her necessary decision.

A quite different kind of "life" is shown in Julius Hart's (1859-1930) poem "In den Frostverglasten Scheiben" ("In the frosty window panes”) from his programmatic Vitalist collection Triumph des Lebens, (Triumph of Life 1898), in which a section-titled Todestanz, (Dance of Death)-has been dedicated to death and decay. The fact alone that a Dance of Deathoccurs within a Triumph of Life may be seen as a re- ference to the dialectic connection between the two aspects.

Julius Hart belonged, together with his brother Heinrich (1855-1906), to the inner circle of the Friedrichshagener poets, who during the 1890s settled in the south-eastern suburb of Berlin. They became a source of inspiration for a new, wide 
ranging poetry influenced by Darwinism, Monism, Vitalism and Oriental mysticism (deBruyn, 1992).

The poem "In den frostverglasten Scheiben" is a vision of death. The lyrical Ilies on his deathbed; above him moon and stars are shining coldly down to him. Through the frosty window the Universe is talking to him about immortality:

Deine Flügel sind entfaltet

über Raum und alle Zeiten,

Tod und Leben sind nur Formen,

Träume dumpfer Sinnlichkeiten.

\section{[...]}

Alle Räume, alle Tiefen

sind von meinem Blut durchflossen,

über allen Welten lieg ich

zeugend, keimend ausgegossen.

Und ich trinke, und ich trinke alles Sein und alles Scheinen aus der Welten grünen Schalen, duftend von gewürzten Weinen.

Alles Sein fließt in mich nieder, und ich selber bin nur Fließen, bin Erzeuger und Erzeugtes, ewig Schaffen und Genießen.

Still im Mondeslichte schwebend trink ich und entström in Gluten, überall spürst du den Atem meiner Silberregenfluten.

[Your Wings are spread,

Over space an all times

Death and life are but forms,

Dreams of blunt sensory perceptions.

\section{[...]}

All spaces, all depths

Are being percolated by my blood,

Over all worlds I lie

Conceiving, poured out sprouting.

And I drink, and I drink

All being and all appearance

From the green bowls of the worlds[!]

With the scent of spiced Wines

\section{All being flows into me \\ And I myself am only floating \\ I am conceiver and conceived \\ Eternal creating and enjoying \\ Quietly soaring in the moonlight \\ I drink and flow out in glowing \\ Everywhere you feel the breath \\ Of my floods of silvery rain.]}

Here, like in Julia Scheuermann's “Leben!”, a pivotal motif is the dissolving of the subject into the totality of the surroundings. In Scheuermann, this happens on the threshold to adult life; here, in Hart's poem, the next station will be death. But nevertheless, in this process the Istays an active subject, and, at the same time, he turns into an object for the same process of change: "I am conceiver and conceived". The traditional relation between subject and object has turned into a mixed, dialectic one. And, to some degree similar to Scheuermann's text, the subject has a fantasy of drinking up the universe, letting all existence flow into him. At the same time his subject widens out to cover the whole universe: "And [I] emerge in glowing, everywhere you feel the breath of my floods of silvery rain”. A simultaneous implosion of the universe and explosion of the subject here characterises Julius Hart's vision of his return to the original totality of life. Again, Rasch's statement of life as a concept surpassing individual life, always seeking the totality of life" become relevant.

Hedwig Dransfeld's (1871-1925) poem "Kirchhofsommer" ("Graveyard-Summer”) shows a far more earth-bound variety of cyclic Vitalism than the one presented in Julie Scheuermann's and Julius Hart's poems. Hedwig Dransfeld-like Julie Scheuermann-belongs to the "Forgotten Poets' Society", and like Scheuermann, Dransfeld had (four) poems elected published for the volume Moderne deutsche Lyrik (1907-edition). The poem quoted here was first published in her Erwachen collection (Awakening), 1903.

The title of the poem contains both the motifs of graveyard and summer and as such suggests the unification of death and life. The first two stanzas elaborate these contrasting motifsvividly. The first stanza starts with a wondering:

So hoch das Gras, die Luft so golden...

Ich träume in den Sommerwind,

warum so üppig hier die Dolden,

So honigschwer die Blüten sind.

Die Knospen bergen kaum den Segen,

Die Rose schwillt im Sonnenkuß..

Ein stürmisch Wachen an den Wegen,

Ein wilder Lebensüberfluß!

[So tall the grass, the air so golden

I dream in the summer wind,

why the umbels so abundant here,

The blossoms so heavy from honey.

The buds can hardly hide the blessing

The rose bulges in the kiss of the sun...

A stormy awakening at the roads,

A wild plethora of life!]

The paradoxical wild growth in this place of death forms the initial theme of the poem. Motifs of life are lined up: Grass, summer, umbels, blossoms, buds, all characterised by their bulging and abundance. All in all: "A wild plethora of life".

In contrast, the second stanza lets the motifs of death emerge:

Und in der Tiefe ruhn die Stillen

So kühl und starr im dunkeln Grab,

Und weiche Sommerregen quillen

als Gruß in ihr Verlies hinab.

Sie ruhn im Schoß der braunen Wände

Und fragen nicht nach Lust und Schmerz,

Und tausend feine Wurzelhände

Andthousandfineroot-hands

umklammern jetzt ihr totes Herz

[And in the depths the silent rest

So cool and stiff in the dark grave,

And soft summer rain runs slowly

As a greeting down into their enclosure. 
They rest in the womb of the brown walls

And don't ask about joy or pain,

And thousand fine root-hands

now clasp their dead heart.]

Here we find quite opposite qualities: quietude, coolness, darkness, rigidity, characteristics of the earth, the bodies and the graves.

The central theme of these two stanzas, however, is not the contrast in quality between life and death, but what combines the two, which is the water, another symbol of life. It slowly soaks though the soil to the dead bodies. The summer rain is a mild, mediating force between the two worlds, between the spheres of life and death. The rain is "soft" and arrives as a "greeting" from above. The whole has a reassuring and friendly quality and certainly no spooky graveyard-atmosphere to it.

Besides the rain, nature builds another "bridge" between the two spheres. The plants have already, before the rain comes, sent down their fine threads into the ground. "And thousand fine root-hands/now clasp their dead heart”.

These two connections between above and below the surface are continued in the third stanza as an on-going bio-chemical process:

Sie ruhn in blauer Nacht verloren, Ermattet nach dem heißen Laufund in die keimgeschwellten Poren saugt sie die durst'ge Erde auf. Sie trinkt der Kinder rinnend Leben, sie schlürft die letzte Faser ein, um aus der toten Kraft zu weben In ihrem Schoß ein neues Sein.

[They rest, as lost in the blue night Exhausted after the warm course-

And the thirsty soil sucks them up

In its pores swelling with seeds.

It drinks the children's running life,

it laps up the last fiber,

to weave from the force of the dead

In her womb a new being.]

In almost shocking, tangible terms the poem here describes the putrefication process. Dransfeld thematises, in a quite new way, physical and anatomical facts that might lead the reader's thoughts to the better known, poems of Gottfried Benn, published eight years earlier in his horrifying and cynical collection Morgue (1912).

In Dransfeld's poem, the motif of life and death in an on-going, biological circuit, is elevated to represent the autonomous Life Force that explains the luxuriant flowering. The last stanza reads:

Das ist die wilde Kraft der Toten, die Licht und Dunkel überbrückt und ihre scheuen Blumenboten mit tausend heißen Farben schmückt!

Die in den schwanken Stielen schauert und lodernd aus den Kelchen brichtdie selbst das Sterben überdauert und in der Tiefe weint nach Licht.

[That is the wild force of the dead which bridges light and darkness

and adorn their timid, flowery messengers

With thousand passionate colours!

Which shivers in the swaying stalks and burning bursts from the calyx-

Which overcomes even death

And in the deep mourns for light.

The conception of a force of life that lingers even in the dead bodies brings the poem to its conclusion. This force connects life and death, "bridges light and darkness", and can be found everywhere in live organisms: "That shivers in the swaying stalks/and burning bursts from flowers' deep”. It overcomes even death and strives for new light, i.e. new life, thus concluding the universal cycle, just to start it all over.

In Dransfeld's poem, neither the mortal nor the vital aspect dominate. The two aspects hold each other in a state of equilibrium, and thus the poem is a fine example of how cyclic Vitalist texts sometimes omit valorising in favour of life or death, but accentuate the dialectics of the two as a totality; that given, in "Kirchhofsommer" we have a paradigmatic example of cyclic Vitalist poetry.

\section{Two Sub-Concepts to Vitalism}

Within the concept of Cyclic Vitalism, we have observed at least two very different notions of the Life Force, for which I will suggest the terms Cosmic and Biological Vitalism. In poems with a universal or cosmic perspective like "In the frosty window pane" by Julius Hart, the dialectics of life and death have an entirely abstract, almost spiritual character. The fusion of life and death is depicted as a cosmic process, taking place far out in the Universe. Julia Scheuermann also imagines life as an omnipresent, universal force, but not of such cosmic character. Life on the one hand is an abstract totality, and on the other a concrete glow inside her and a tangible, roaring stream before her. Her concept of life nevertheless can be seen as a cosmic one, compared to the poem by Hedwig Dransfeld, in which the cyclic processes connected to life are much more down to earth, one could truly say. With "Graveyard-Summer", we move into the sphere of biology and physiology. Life here is closely connected to the processes of growth, decay, decomposition and rebirth.

By means of differentiation of concepts-in this case the distinction between Cosmic and Biological Vitalism-our interpretations can bring us somewhat further in our understanding of the variations in Vitalist thinking, variations that cannot necessarily be noticed by means of traditional categories of interpretation and categorisation. Neither here nor in any other contexts, should interpreters be content with only one central stock phrase to cover what previously has been described as "a current". Vitalism as a concept and its differentiations "cyclic", "cosmic" and "biological" suggest how to deconstruct and in a new way throw light on hitherto marginalised or underestimated aspects of poetry-and other cultural expressions-from 1890 until 1930, although some believe that its relevance extends until 1940, or even to the present day.

\section{REFERENCES}

Andersen, L. P. (2011). The Advent of the natural woman. In G. Hvidbjerg-Hansen, \& G. Oelsner (Eds.), The spirit of vitalism. Health, 


\section{S. HALSE}

beauty and strength in Danish art 1890-1940 (pp. 198-217). Copenhagen: Museum Tusculanum.

Benzmann, H. (1903). Moderne deutsche Lyrik. Mit einer literaturgeschichtlichen Einleitung und biographischen Notizen herausgegeben von Hans Benzmann. Leipzig: Philipp Reclam Junior.

De Bruyn, G. (ed.) (1992). Friedrichshagen und seine Dichter. Arkadien in Preußen. Berlin: Verlag Morgenbuch.

Bühler, B. (2004). Lebende Körper. Biologisches und anthropologisches Wissen bei Rilke, Döblin und Jünger. Dissertation, Würzburg.

Dam, A. E. (2010). Den Vitalistiske strømning i dansk litteratur omkring 1900. Aarhus: Aarhus Universitetsforlag.

Dam, A. E. (2011). Music is life. Carl Nielsen's Vitalistmusical philosophy. In G. Hvidbjerg-Hansen, \& G. Oelsner (Eds.), The spirit of vitalism. Health, beauty and strength in Danish art 1890-1940 (pp. 276-285). Copenhagen: Museum Tusculanum.

Driesch, H. (1922). Geschichte des Vitalismus. Leipzig: Verlag von Hans Ambrosius Barth.

Halse, S. (2011). Wide-ranging vitalism: On the concept and phenomenon of vitalism in philosophy and art. In G. Hvidbjerg-Hansen, \& G. Oelsner (Eds.), The spirit of vitalism. Health, beauty and strength in Danish art 1890-1940 (pp. 46-57). Copenhagen: Museum Tusculanum.

Halse, S. (2013). Zyklischer Vitalismus. Die Dialektik von Tod und Leben in der deutschen Lyrik um 1900. In Sandbjerg/Paulsen (Ed.),
Natur und Moderne. Räume, Repräsentationen, Medien (pp. 203218). Bielefeld: Transcript Verlag.

Hein, H. (1972). The Endurance of the mechanism-vitalism controversy. Journal of the History of Biology, 5, 159-188. http://dx.doi.org/10.1007/BF02113490

Hvidberg-Hansen, G., \& Oelsner, G. (2011). Thetriumph of life. The spirit of vitalism. Health, beauty and strength in Danish art 18901940. 10-45.

Munch, A. V. (2011). Framing the life-rhythm.On the vitalization of architecture. In G. Hvidbjerg-Hansen, \& G. Oelsner (Eds.), The spirit of vitalism. Health, beauty and strength in Danish art 1890-1940 (pp. 106-125). Copenhagen: Museum Tusculanum.

Nørlyng, O. (2011). Dancing Life Iteself. In G. Hvidbjerg-Hansen, \& G. Oelsner (Eds.), The spirit of vitalism. Health, beauty and strength in Danish art 1890-1940 (pp. 250-275). Copenhagen: Museum Tusculanum.

Oelsner, G. (2011) Healthy Nature. In G. Hvidbjerg-Hansen, \& G. Oelsner (Eds.), The spirit of vitalism. Health, beauty and strength in Danish art 1890-1940 (pp. 158-197). Copenhagen: Museum Tusculanum.

Rasch, W. (1967). Aspekte der deutschen Literatur um 1900. Zur deutschen Literatur seit der Jahrhundertwende. Stuttgart: J.B. Metzler.

Riedel, W. (1996). Homo natura. Literarische Anthropologie um 1900. Berlin, N.Y.: de Gruyter. http://dx.doi.org/10.1515/9783110812404 